\title{
Sources of error in neonatal blood sampling
}

\author{
H PATEL, S W RYAN, AND B McLAIN \\ Department of Paediatrics and Child Health, General Infirmary, Leeds
}

\begin{abstract}
SUMMARY Significant underestimation of blood electrolyte concentrations may occur if less than $1 \mathrm{ml}$ of blood is withdrawn from an indwelling arterial line before taking the sample for analysis. Compared with arterial samples capillary samples give significant overestimations of potassium concentration and carbon dioxide tension, and significant underestimation of oxygen tension.
\end{abstract}

Blood samples are regularly taken from sick neonates for measurement of electrolyte concentrations, blood gases, and $\mathrm{pH}$. Our experience is that such samples are not collected in a uniform way. Standard reference works indicate how to site and take blood from indwelling arterial lines ${ }^{1}$ but give no advice about the volume of fluid (flush volume) to remove before sampling in order to obtain accurate results. Blood counts may vary depending on the sampling site, ${ }^{2}$ and we have encountered spuriously abnormal electrolyte and blood gas measurements from both capillary and arterial samples. We have therefore examined the effects of two different flush volumes and capillary sampling on measurements of electrolyte concentrations and blood gases.

\section{Methods}

We studied the results of all blood samples taken during a three month period from infants on the neonatal unit who had a peripheral or umbilical arterial line in situ. Lines were infused at $1 \mathrm{ml} /$ hour with $5 \%$ glucose solution containing 1 unit $/ \mathrm{ml}$ sodium heparin. The gestational age of the infants ranged from 26 to 42 weeks, and all were stable at the time of sampling with no clinical evidence of right to left ductal shunting. Arterial sampling started with the withdrawal of $0.5 \mathrm{ml}$ of fluid $(0.5 \mathrm{ml}$ total flush) followed by the withdrawal of $0.2 \mathrm{ml}$ for analysis. A further $0.3 \mathrm{ml}$ was then withdrawn $(1.0 \mathrm{ml}$ total flush) and the next $0.2 \mathrm{ml}$ sample taken; $0.8 \mathrm{ml}$ was then withdrawn $(2 \mathrm{ml}$ total flush), and a final $0.2 \mathrm{ml}$ sample taken. The $1.6 \mathrm{ml}$ of fluid removed but not used for analysis was then returned to the patient. A $2 \mathrm{ml}$ flush volume was chosen to minimise haemodynamic consequences for the infant. Evaluation of arterial lines in vitro had shown that a $2 \mathrm{ml}$ flush volume resulted in sample dilution of only $0 \cdot 2 \%$.
A capillary sample of $0.2 \mathrm{ml}$, was taken immediately from the unwarmed heel at the same time as Dextrostix measurement was carried out. Parental consent was obtained and no infant underwent more than two procedures.

Each sample was analysed for $\mathrm{pH}$, oxygen tension $(\mathrm{kPa})$, and carbon dioxide tension $(\mathrm{kPa})$ with a Corning $178 \mathrm{pH} / \mathrm{blood}$ gas analyser. Measurement $(\mathrm{mmol} / \mathrm{l})$ of plasma sodium and potassium concentrations was done with a Corning $902 \mathrm{Na}-\mathrm{K}$ analyser.

Statistical analysis was by the paired Student's $t$ test.

\section{Results}

Forty three sets of samples were obtained for blood gas analysis and 40 sets for measurement of electro-

Table 1 Mean (SD) differences in electrolyte measurements between other samples and $2 \mathrm{ml}$ flush samples

\begin{tabular}{|c|c|c|c|}
\hline \multirow{2}{*}{$\begin{array}{l}\text { Plasma } \\
\text { electrolyte } \\
\text { concentrations } \\
\text { (mmol/l) }\end{array}$} & \multicolumn{3}{|c|}{ Type of sample } \\
\hline & $\begin{array}{l}0.5 \mathrm{ml} \\
\text { flush }\end{array}$ & $\begin{array}{l}1.0 \mathrm{ml} \\
\text { flush }\end{array}$ & Capillary \\
\hline $\begin{array}{l}\text { Sodium } \\
\text { p Value }\end{array}$ & $\begin{array}{l}-8 \cdot 3(7 \cdot 0) \\
<0 \cdot 001\end{array}$ & $\begin{array}{l}-1 \cdot 7(2 \cdot 3) \\
<0 \cdot 001\end{array}$ & $\begin{array}{l}0 \cdot 0(2 \cdot 2) \\
\text { NS }\end{array}$ \\
\hline $\begin{array}{l}\text { Potassium } \\
\text { p Value }\end{array}$ & $\begin{array}{l}-0.41(0.60) \\
<0.001\end{array}$ & $\begin{array}{l}-0.18(0.49) \\
<0.01\end{array}$ & $\begin{array}{l}1.22(0 \cdot 96) \\
<0.001\end{array}$ \\
\hline
\end{tabular}

Table 2 Mean (SD) differences in $\mathrm{pH}$ and blood gas measurements between other samples and $2 \mathrm{ml}$ flush samples

\begin{tabular}{|c|c|c|c|}
\hline \multirow[t]{2}{*}{ Measurement } & \multicolumn{3}{|c|}{ Type of sample } \\
\hline & $\begin{array}{l}0.5 \mathrm{ml} \\
\text { flush }\end{array}$ & $\begin{array}{l}1.0 \mathrm{ml} \\
\text { flush }\end{array}$ & Capillary \\
\hline Blood pH & $\begin{array}{c}-0 \cdot(014 \\
(0 \cdot(036)\end{array}$ & $\begin{array}{c}-0 \cdot 002 \\
(0 \cdot 015)\end{array}$ & $\begin{array}{c}-0 \cdot(023 \\
(0 \cdot 038)\end{array}$ \\
\hline p Value & $<0 \cdot 02$ & NS & $<0 \cdot 001$ \\
\hline $\begin{array}{l}\text { Oxygen ténsion } \\
\text { (kPa) } \\
\text { p Value }\end{array}$ & $\begin{array}{l}0 \cdot 19(0 \cdot 83) \\
\text { NS }\end{array}$ & $\begin{array}{l}\text { NS } \\
0 \cdot(02(0 \cdot 61)\end{array}$ & $\begin{array}{l}-2 \cdot 40(1 \cdot 54) \\
<0 \cdot 001\end{array}$ \\
\hline $\begin{array}{l}\text { Carbon dioxide } \\
\text { tension }(\mathrm{kPa}) \\
\text { p Valuc }\end{array}$ & $\begin{array}{l}-0.39(0.56) \\
<0.001\end{array}$ & $\begin{array}{l}-0.05(0.36) \\
\text { NS }\end{array}$ & $\begin{aligned} & 0.52(0.83) \\
< & 0 \cdot(001\end{aligned}$ \\
\hline
\end{tabular}


lyte concentrations from 34 infants. The results of the sodium and potassium measurements are shown in table 1 and those for $\mathrm{pH}$ and blood gas measurements in table 2.

\section{Discussion}

When sampling blood from neonates it is necessary to keep cumulative blood loss to a minimum by using small sample volumes $(0 \cdot 2 \mathrm{ml}$ in this study), by limiting the number of samples that need to be repeated because of spuriously abnormal results, and by carefully assessing the clinical need for blood analysis before sampling.

The study confirmed our impression that sampling from arterial lines may result in erroneous results and hence possible unnecessary treatment. The underestimation of plasma sodium, potassium, and $\mathrm{PCO}_{2}$ concentrations resulted from dilution of arterial blood with the small volume of $5 \%$ glucose solution in the arterial line. The smaller the flush volume of arterial blood, the greater the dilution. The mixing of $5 \%$ glucose solution (which has a $\mathrm{pH}$ of 5) with arterial blood led to the significantly lower $\mathrm{pH}$ concentrations at flush volumes of $0.5 \mathrm{ml}$.

Concentrations of potassium in capillary blood were higher than those in arterial blood in 38 out of 40 specimens, the mean value being more than $1 \mathrm{mmol}$ higher but with a wide variation (SD 0.96). A high potassium concentration in a capillary sample should be confirmed by measuring the concentrations in a venous or arterial sample, the latter following a $2 \mathrm{ml}$ flush if taken from an indwelling arterial line. There were significant differences between measurements in blood gases in capillary and arterial blood with a moderate rise in carbon dioxide tension in capillary blood and a larger reduction in oxygen tension in capillary blood (mean reduction $2.4 \mathrm{kPa}$ ), but the degree of clinical importance varied unpredictably among patients.

In conclusion, blood samples taken from arterial lines should be preceded by an adequate flush; we regard a $2 \mathrm{ml}$ flush volume as ideal. Capillary blood samples may give erroneously high potassium concentrations even in the absence of obvious haemolysis. Unexpectedly abnormal results should be checked by measuring the concentrations in arterial or free flowing venous blood.

\section{References \\ 1 Wilkinson A, Calvert S. Procedures in neonatal intensive care. In: Roberton NRC, ed. Textbook of neonatology. Edinburgh: Churchill Livingstone, 1986:817-35. \\ 2 Thurlbeck SM, McIntosh N. Preterm blood counts vary with sampling sitc. Arch Dis Child 1987:62:74-5.}

Correspondence to Dr SW Ryan, Department of Paediatrics and Child Health, Clarendon Wing. General Infirmary, Leeds LS2 9NS.

Accepted 14 March 1988

\title{
Cytomegalovirus screened blood for neonatal intensive care units
}

\author{
S LOGAN, ${ }^{*}$ J BARBARA, $\dagger$ AND I KOVAR* \\ ${ }^{*}$ Department of Child Health, Charing Cross and Westminster Medical School, London, and $†$ North London \\ Blood Transfusion Centre, Edgware, Middlesex
}

\begin{abstract}
Summary Two infants were considered to have acquired cytomegalovirus (CMV) infection from blood transfusions screened for the presence of CMV antibody by a haemagglutination assay. Further samples from the same donors were tested by a latex agglutination test; six of $18(33 \%)$ previously believed seronegative were found to be seropositive.
\end{abstract}

The risk of premature infants acquiring cytomegalovirus (CMV) infection from a blood transfusion can be reduced if blood components negative for CMV are used. ${ }^{1}$ In this unit all premature babies receive blood screened for CMV. We describe two cases in which CMV infection occurred despite this policy, and discuss the implications for the provision of blood negative for CMV for neonatal intensive care units.

\section{Case reports}

CASE 1

A female infant was born at 29 weeks' gestation weighing $1200 \mathrm{~g}$. After early problems she progressed well until on day 50 she deteriorated suddenly. Blood cultures grew a group A $\beta$ haemolytic streptococcus. She responded to intravenous antibiotics and was discharged well at 3 months of age.

CMV was isolated from her urine at the time of her deterioration. Routine screening for CMV at birth was negative, and her mother was seronegative for CMV. 